\title{
المشاركة المجتمعية و تحسين جودة حياة أسر الأطفال ذوي الاحتياجات الخاصة ( دراسة تحليلية )
}

\author{
إعراد \\ الباحث/ أمل نبيه أبو اليزيل متولي \\ معيدة بقسم أصول تربيت الطفل \\ كليتر رياض الأطفال - جامعت المنصورة
}

اشراف

دا وليد سامي حسن

مدرس أصول تربيتيت الطفل

كليت رياض الأطفال - مدرل جامعتمتاضلمنصورة الأفال

$$
\begin{aligned}
& \text { المجلت العلميت لكليت رياض الأطفالـ جامعت المنصورة } \\
& \text { المجلد الرابع ـ العدد الثانى }
\end{aligned}
$$

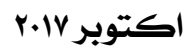




\section{الشاركة المجتمعية و تحسين جودة حياة أسر الأطفال

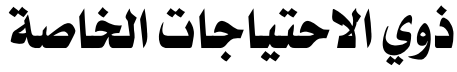 \\ ( دراسة تحليلية )}

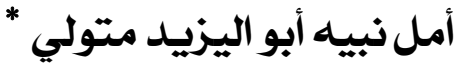

\section{مقدمة}

تعد المشاركة المجتمعية أحد أثنكال التعبير عن حيـاة الإنسسان؛ حيــث

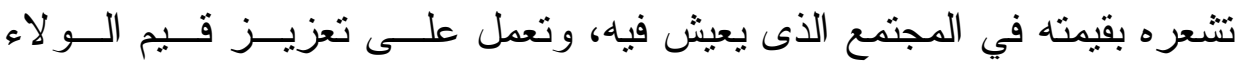

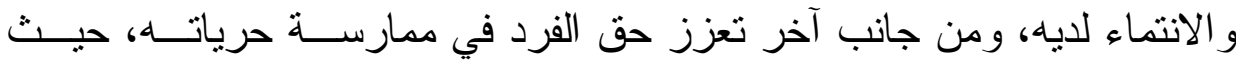

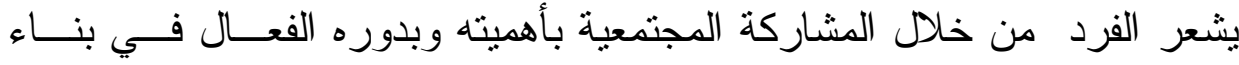

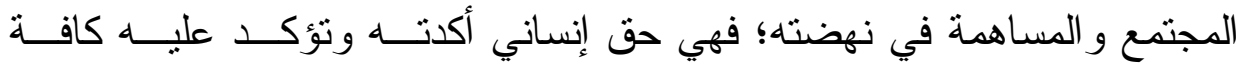

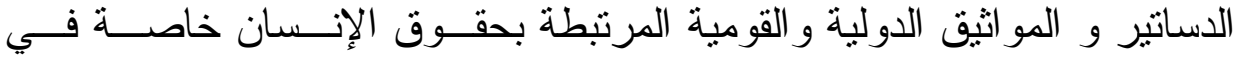

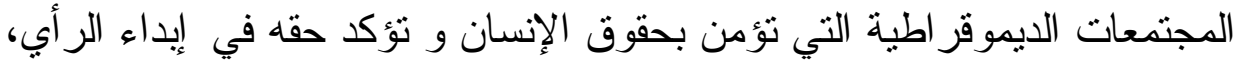

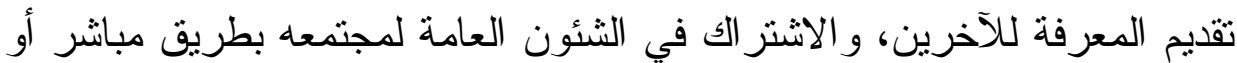
غير مباثر ، و المشاركة بحرية في الحركة الثقافية لمجتمعه (')

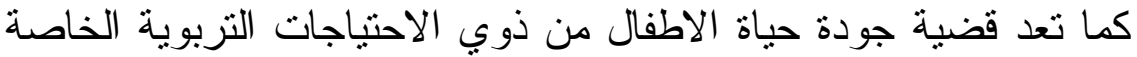

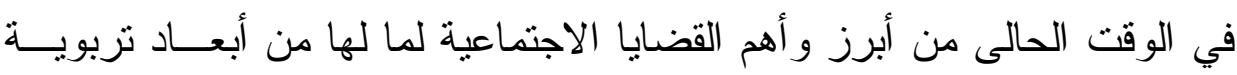

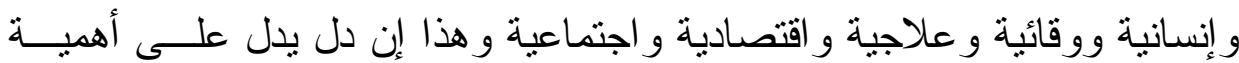

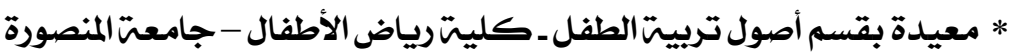

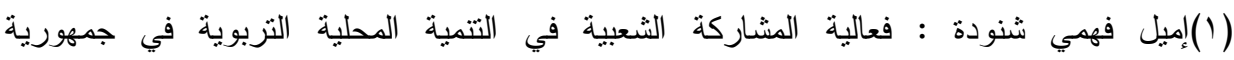

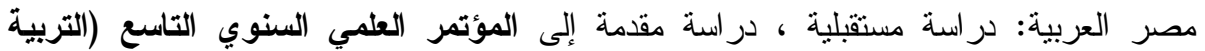

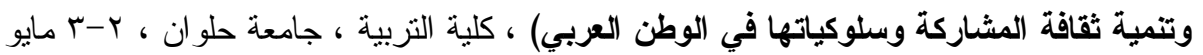
$.096 r . .1$

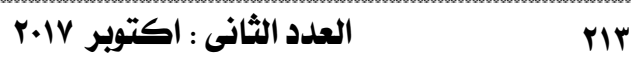
المجلد الرابع 


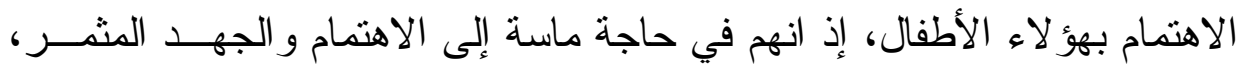

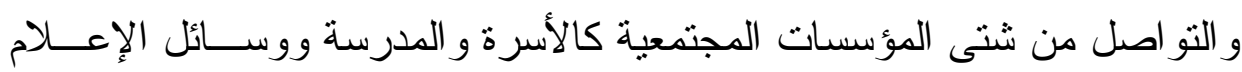

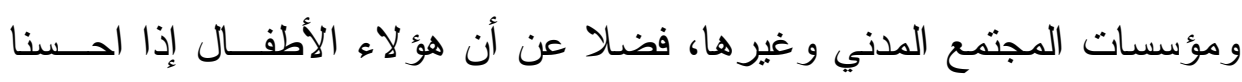

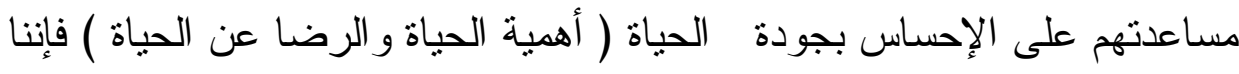

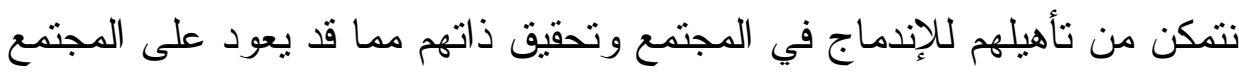
بالخير و المنفعة (1).

هذا ، ولقد أصبح الاهتمام بالأفر اد من ذوي الاحتياجات التربوية الخاصة

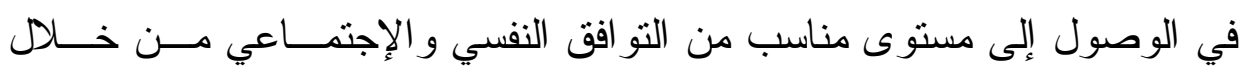

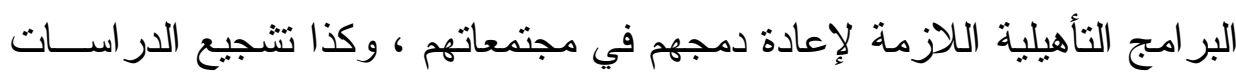

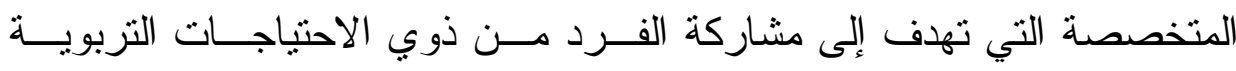

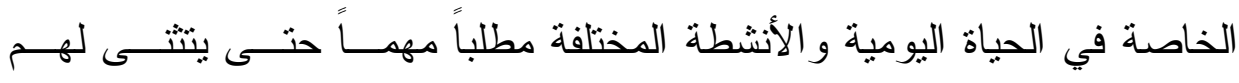

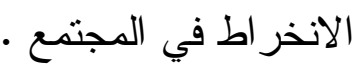

مشكلة الار اسة

نظر الما نوليه دول العالم المعاصــر مــن اهتمــام بتفعيـلـ المـشاركة

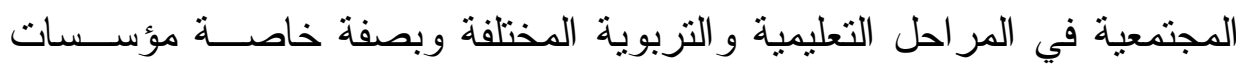
رياض الأطفال، فقد حرصت تلك الدول على أن تتمتع مؤسسات رياض الأطفال

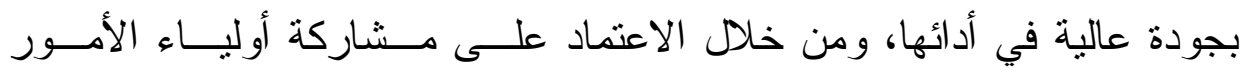

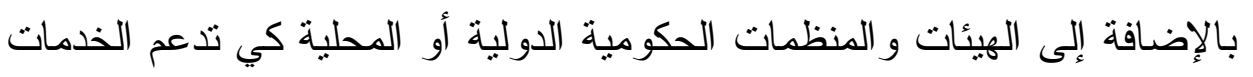

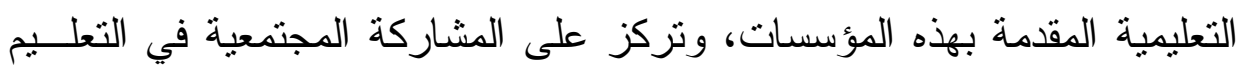

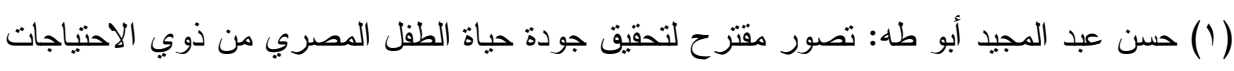

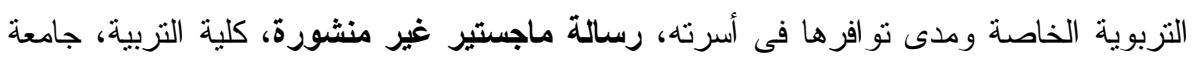

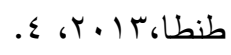


في مثل هذه الدول في إعادة بناء الدولة وتطوير أنظمتها وبصفة خاصة النظـــام

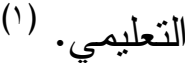

ورغم الاهتمام الرسمي و الأهلى برعاية وتربية الأطفال ذوي الاحتياجات

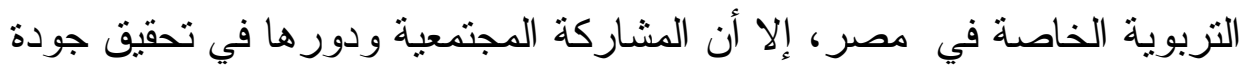

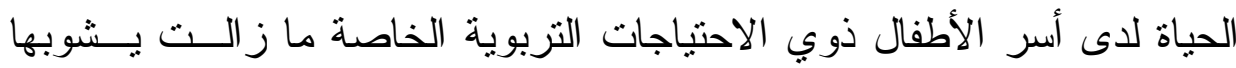

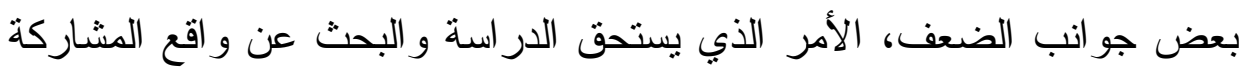

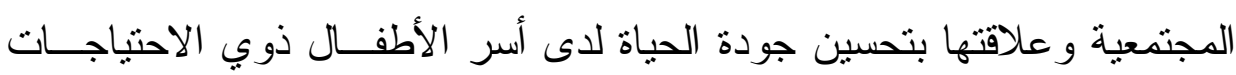
التزبوية الخاصة تحديدا للمفاهيم و المعوقات و آليات التفعيل. لذا تسعي الدراسة الحالية للإجابة عن النساؤلات التالية: () ما الإطار المفاهيمي للمشاركة المجتمعية؟ r) ما الإطار التربوي لجودة حياة أسر الأطفال ذوي الاحتباجات التربوية

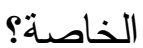
r) كبف تسهم المشاركة المجتمعية في تحسين جودة حياة أسر الأطفال ذوي

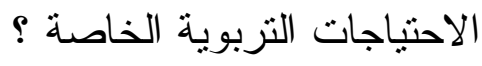
أهمية الار اسة تتضح أهمبة الدر اسة في: •توضيح طبيعة المشاركة المجتمعية واهيتها في تحسين جودة الحياة علىى الهي درجة كبيرة من الأهمية، تساعد المعلمات على فهم وتطبيق هذه المـشاركة

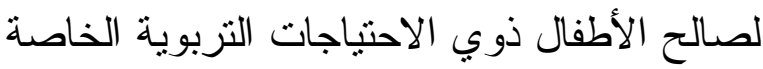
(') السيد عبد القادر شريف: المشاركة المجتمعية في رياض الأطفال، حورس للطباعة والنشر،

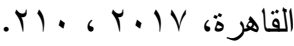


•توضيح طبيعة جودة الحياة على درجة كبيرة من الأهمية، تـساعد الآبــاء

و الأمهات على فهم وتطبيق هذه المشاركة لصالح الأطفال ذوي الاحتياجات

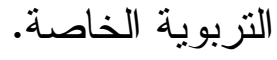

• سد الخلل في المكتبة العربية لندرة الأبحاث التي تتاولت علاقة المـشاركة المجتمعية بتحسين جودة الحياة للأطفال ذوي الاحتياجات التربوية الخاصة.

\section{منهج الدراسة}

ينطلق البحث الر اهن بالتعريف بالاطار الدفاهيمي للمشاركة المجتمعية ـ

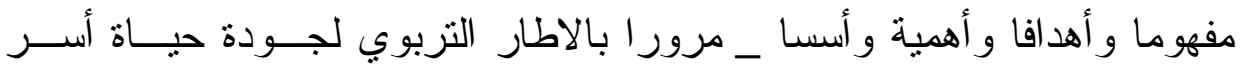
الأطفال ذوي الاحتباجات الخاصة، و المعوقات التي تحول دون ضمانها؛ بهـدف

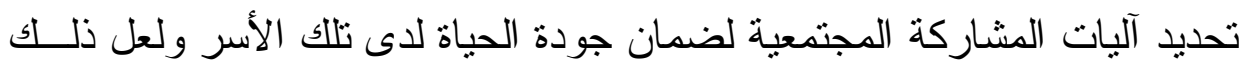
يناسبه انتهاج المنهج الوصفي منهجا للبحث الر اهن • لئان مصطلحات الدراسة

تتضمن الاراسة الحالية عددا من المصطلحات الأساسية أهمها : ا المشاركة المجتمعية The Community Participation

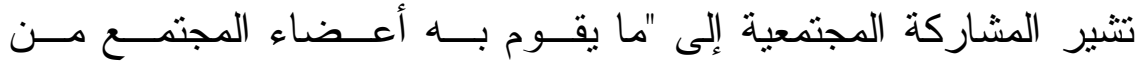

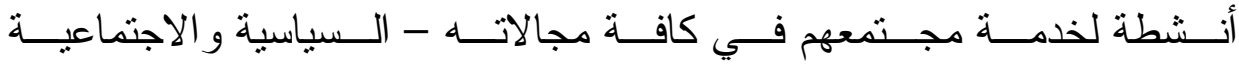

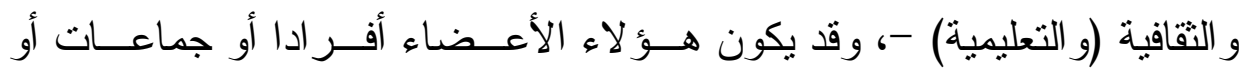

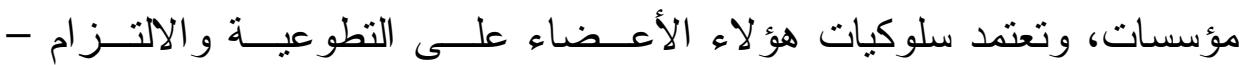

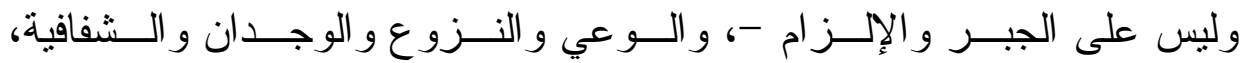




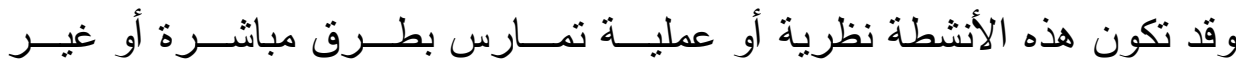

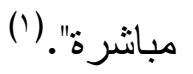

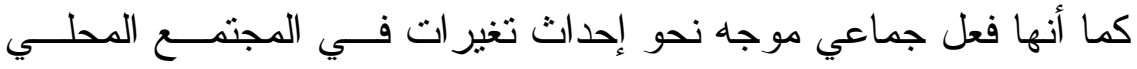

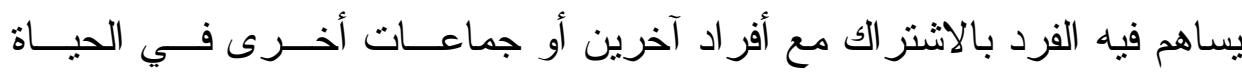

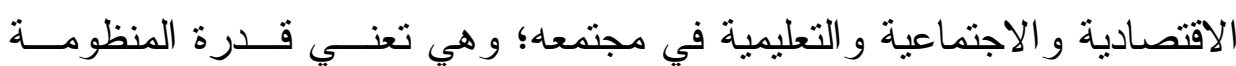

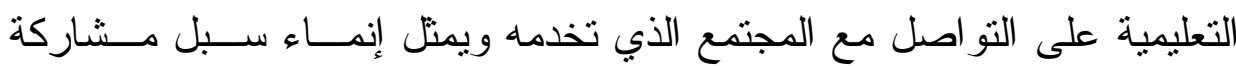

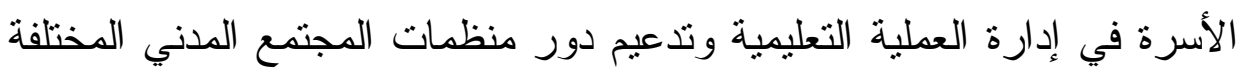

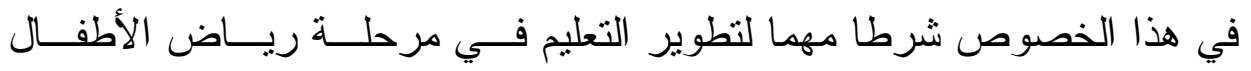

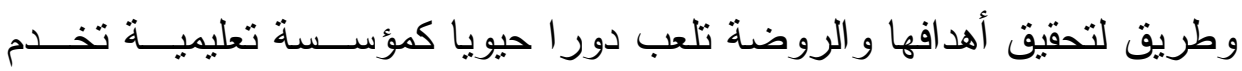

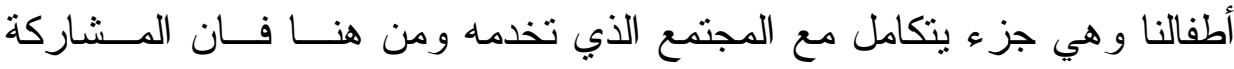

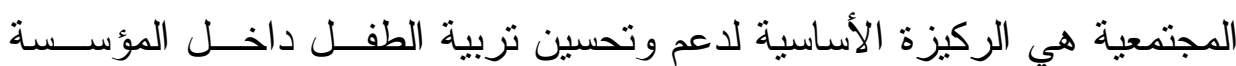
التزبوية. (r)

وتعرف الباحثة المشاركة المجتمعية إجرائيا في هذه الدراسة: بأنها الأنشطة و الممارسات المجتمعية التي تقوم بهـــا أفــر اد ومنظمــات

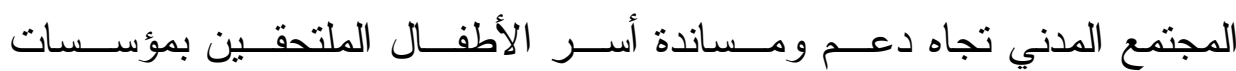

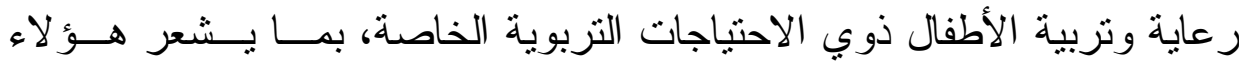

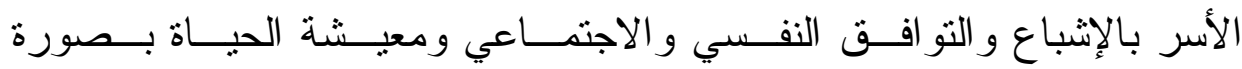

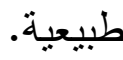

(1) محمد حسنين العجمي: المشاركة المجتمعية والإدارة الذاتية للمدرسة ،العالمية للنشر و التوزيع ،

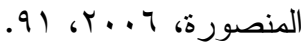
(Y) السيد عبد القادر شريف: مرجع سابق، • ع. (r) 
جودة الحياة Quality Life

يعتبر مفهوم جودة الحياة اسما جديدا لفكرة قديمة؛ فهو المعنى الذاتي الذي يعبر به الناس عما يعرف بحسن الحال أو الوجود الافضل، و عادة ما يعبر عـن القدئ مفهوم جودة الحياة بمجموعة من الاحتياجات التي إذا شبعت سويا تجعل الفـرد بـرد سعيدا أو ر راضيا. (') كما يعرف "بأنه مجموع تقييمات الأفر اد لجوانب حياتهم اليومية في وقت محدد وفي ظل ظروف معينة، و إدر اكهم لمكانتهم ووضعهم في الحياة في محيط المنظومة النقافية و القيمية التي يعيشون فيها وعلاقة ذلك بأهــافهر وتوقهـاتهر ومعايير هم و اهتماماتهم في ضوء تقييمهم للجو انب التالية:

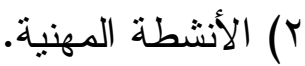

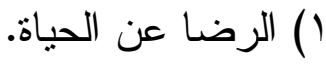

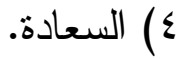
r) - ( أنثطة الحياة اليومية.

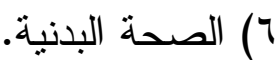

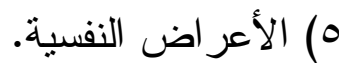

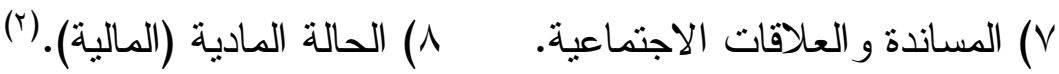
وتعرف الباحثة جودة الحياة إجرائيا في هذه الدراســة: هـي مسستوى

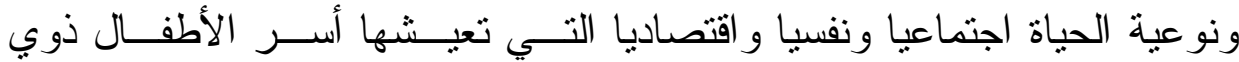

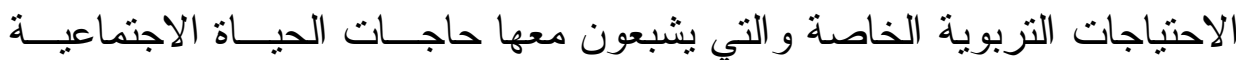

(1) محمد السعيد أبو حلاوة: "جودة الحياة الدفهوم و الأبعاد "، المؤتمر العلمي السابع "جودة الحياة

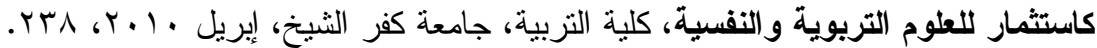

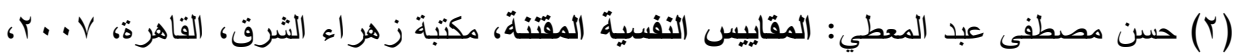
$\cdot v$ 
و المعيشة من التو افق النفسي و الاجتماعي و التكيف الإيجابي مع المجتمع المحيط، بما يشعر هم بالقبول و الرضا و السعادة.

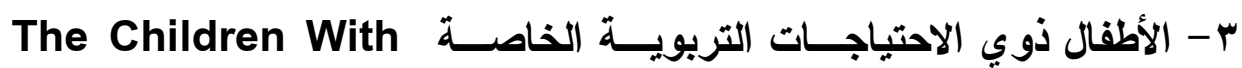

\section{Special Needs}

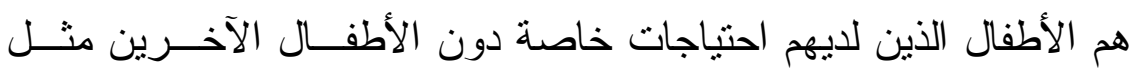

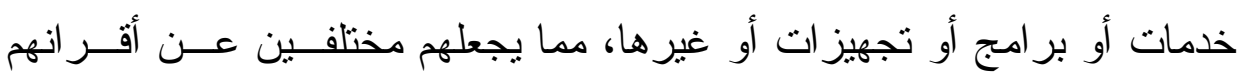
و وأولى عنهم بالر عاية.

و الفرد ذو الحاجة الخاصة هو " كل فرد يعاني - نتيجة عو امل ور اثيــة|

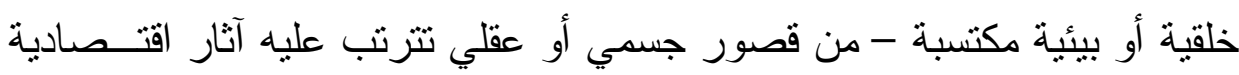

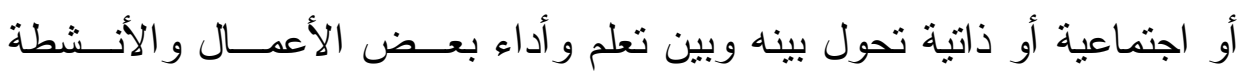

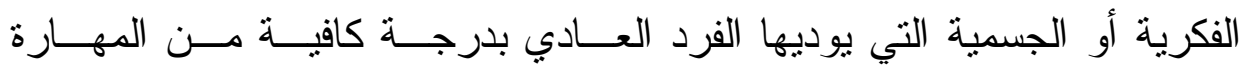
و النجاح. (')

وتعرف الباحثة الأطفال ذوي الاحتياجات التربوية الخاصة إجرائيا فـي هـــه الار اسة: أبرف

بأنهم الأطفال الذين لايهم إعاقات حسية أو جسمية أو عقلية أو اجتماعية،

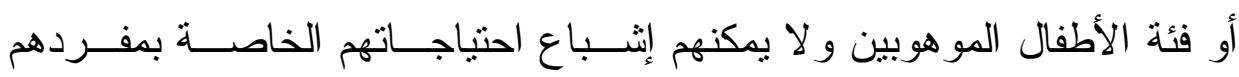
ويحتاجون لمن يقدم لهم الرعاية المناسبة.

(1) عثمان لبيب فراج: الإعاقات الذهنية في مرحلة الطفولة، المجلس العربي للطفولة والتتمية،

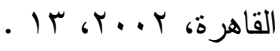




\section{المحور الأول: الإطار المفاهيمي للمشاركة المجتمعية}

تعد المشاركة المجتمعية في التعليم عامة وتعليم ذوى الاحتياجات التربوية

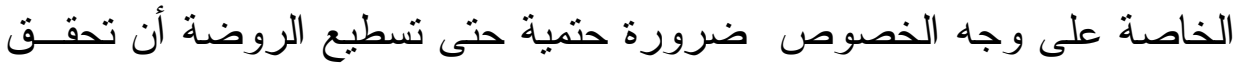

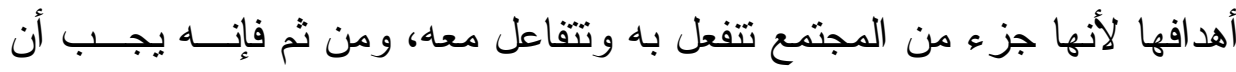

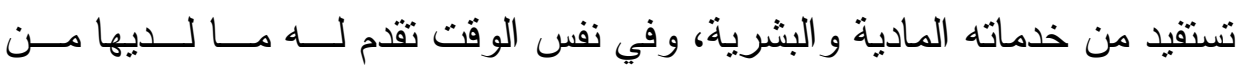

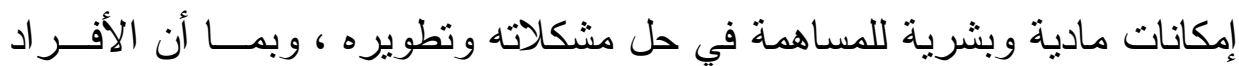

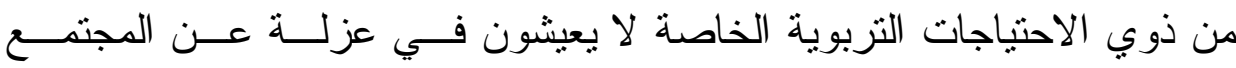

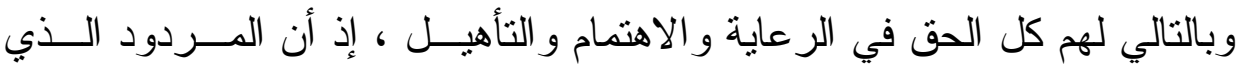

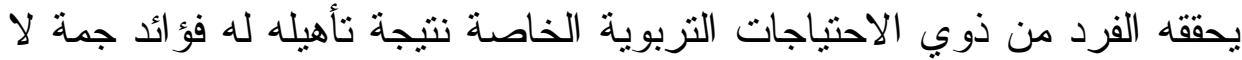

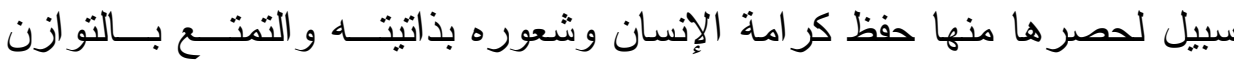

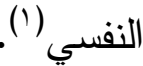

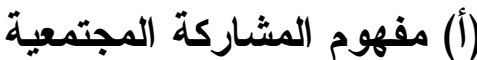

يعرف المعجم الوجيز الفعل أثنرك بمعنى أدخل أى جعـل لــهـ شــريكاً،

$$
\text { و الثريك هو مشاركة غيره في شئ ما (r). }
$$

كما عرفها " ابن منظور في لسان العرب" أن التشارك يعنى المشاركة في

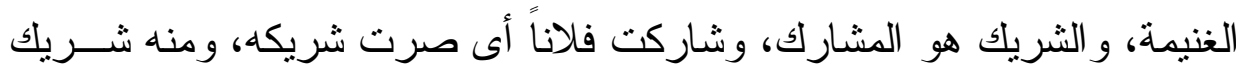

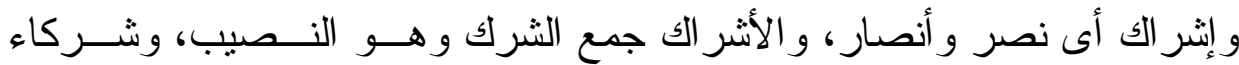

(1)Warner, K., Hull, K., \& Laughlin, M. :The Role of Community in Special Education: A Relational Approach. In Interdisciplinary Connections to Special Education: Important Aspects to Consider, 2015, (pp. 151-166). Emerald Group Publishing Limited.

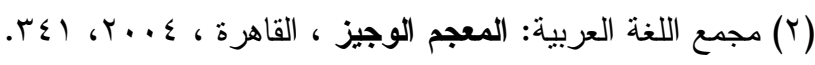


بمعنى مستوون في الثئ، وطريق مشترك أى طريق يـسـتوى فيــهـ النــاس (')؛ وبذلك يحمل مفهوم المشاركة المجتمعية دلالة لغوية مفادها أن هناك نشارك بــنت بين فئتين أو كثر بحيث يصبحو ا مسئولين عن تحقيق نجاح ما .

ويتضمن الفكر الإنساني المعاصر بعض المصطلحات التي تـشير إلـى معنى المشاركة من جانب أو آخر ومنها مفهوم المشاركة، الثر اكة، و التطوعية،

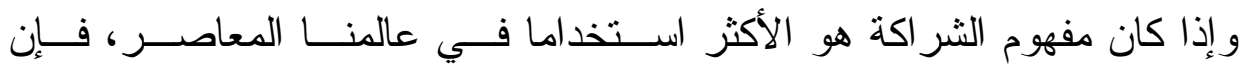

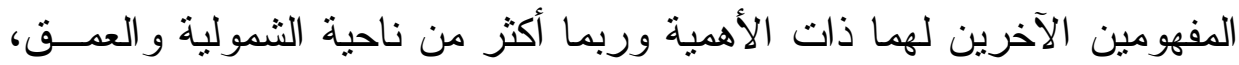
و المشاركة هي أكثر قوة وعمقا من الثر اكة، خاصة أن الثر اكة يمكن أن تمثــلـ

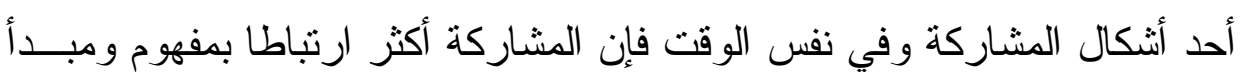
التطو عية (r) (الن) ويطلق البعض على مصطلح المشاركة المجتمعية مصطلح " المـشـاركة الشعبية القاعدية" وتعني به تحريك همح وطاقات المو اطنين في المجتمع المحلـي للإسهام في مواجهة تحديات التتمية البشرية، وهو ما يشير إلى أهمية الدور الذي يقوم به المجتمع المدني لحفز الطاقات وتعبئة العمل التطوعي (مان. ففي إطار ارنباط المشاركة بالمجال الاجتماعي، فـيمكن تعريفهــا بأنهـــا

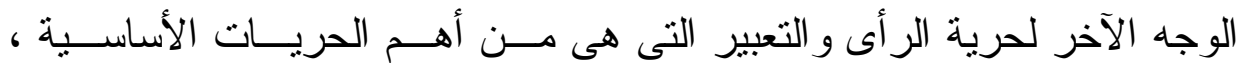
باعتبار ها حق من حقوق الإنسان المعاصر و التى تقر به الهيئات العالمية لحقوق

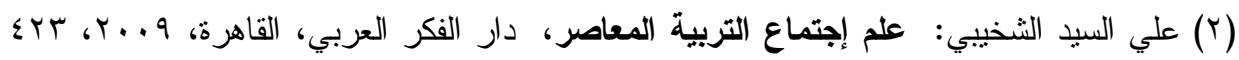
. $\{r \leqslant-$

(ץ) أماني قنديل: دور الجمعيات الأهلية في تتفيذ الأهداف الإمائية جمعية العزيمة الإسلامية،

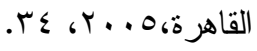


الإنسان، وفي إطار ارتباط المشاركة بالمجالين السياسي و الاجتماعي معاً تعرف

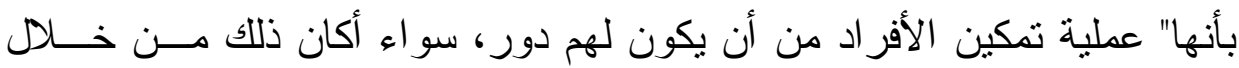

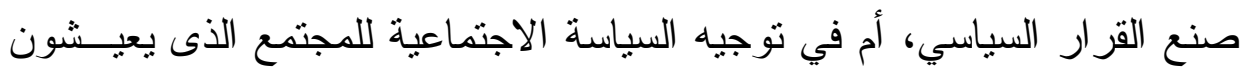

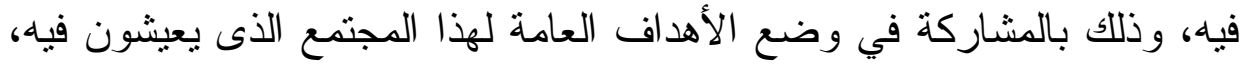

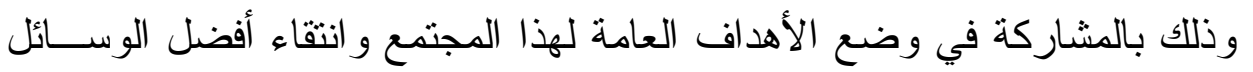

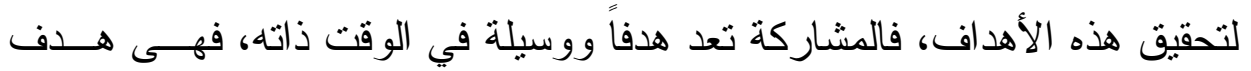

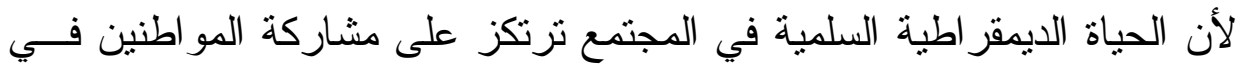

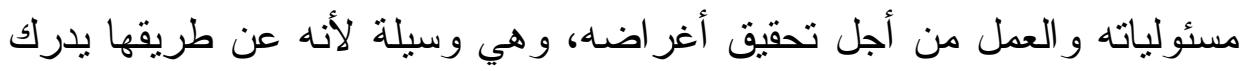
الأفر اد و الجماعات أهميتها وقيمتها ويمارسون أساليبها ووسائلها ('). ومن منظور حقوق الإنسان ينظر إلى المشاركة المجتمعية على أنهــا "

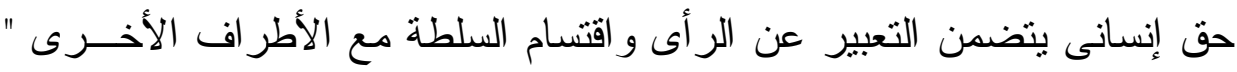

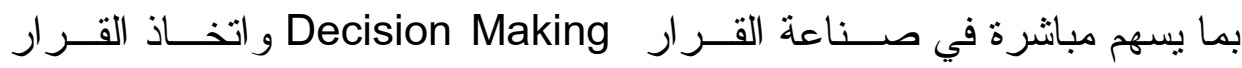

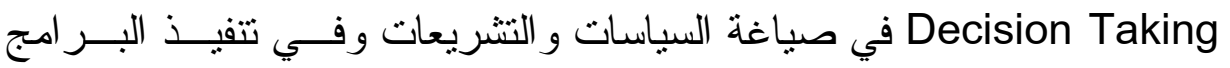

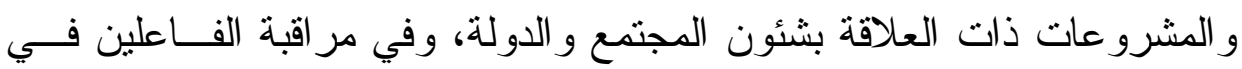
المو اقع المختلفة ومساءلتهم (؟).

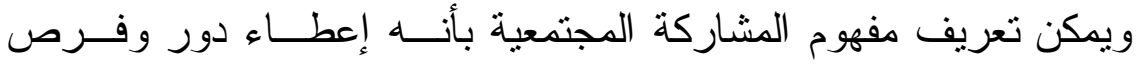

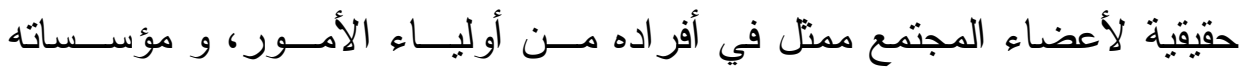

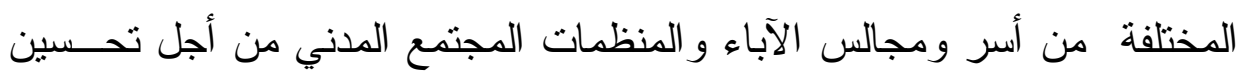
جودة حياة وتعلم الأطفال ذوى الاحتياجات التربوية الخاصة.

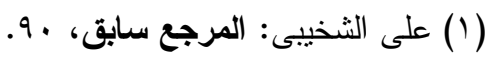
(ץ) عبد الباسط عبد المعطى: علم اجتماع التتمية، قضايا معاصرة ، جامعة عبن شس، القاهرة ،

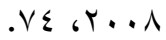




\section{(ب) (أهمية المشاركة المجتمعية}

للمشاركة المجتمعية أهمية كبرى حيث تعمل على تتمية الثعور القـومى بالانتماء وتقضى على مظاهر السلبية والاتكالية، فهى قيمة اجتماعية في ذاتهـا ونهجاُ اجنماعياً يحقق الكثير من المز ايا (')

ليس هذا فحسب ، ولكن يمكن أن تحقق المشاركة المجتمعية العديد مـن

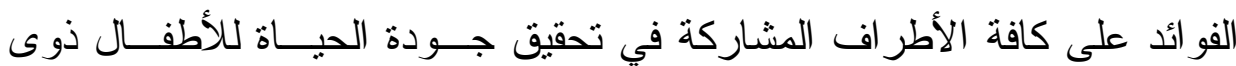
الاحنياجات التربوية الخاصة و التى جاءت على النحو التالى:

1-زيادة الموارد؛ حيث تعمل على توفير أعداد أكبر من المــوارد الماديــة

$$
\text { و البشرية. }
$$

r- تعدد الخيارات: نتيجة لزيادة الأطر اف فإن هنالك عدد المـشاركين مسن

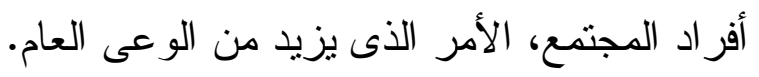

r- تقوية المؤسسات: عن طريق تبادل الخبرات و المعلومات بــين الجهـات

$$
\text { المشاركة مما يدعم ويقوى كل جهة على حدة. }
$$

ع - تتمية رأس المال الاجتماعي: الذى يعرف بأنه تـــر اكم الدــوارد الماديـــة

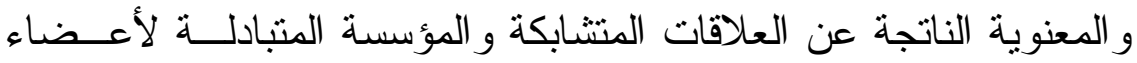

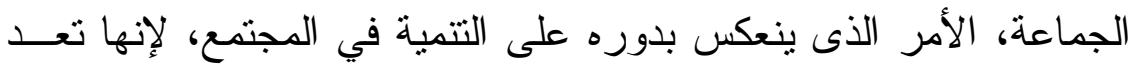

$$
\text { وسيلة لإدارة العمل الجماعي (؟). }
$$

(1) Talò, C., Others :Sense of community and community participation: A metaanalytic review. Social indicators research, $\operatorname{Vol}(1), \operatorname{No}(117)$,2014,pp 128.

(2) Pryor, J. : Can community participation mobilise social capital for improvement of rural schooling? A case study from Ghana. Compare: A Journal of Comparative and International Education, Vol.(2), No.(35), 2005,pp 193-203. 
وقد أكد تقرير التتمية البشرية لعام بـ. بام على أن المشاركة المجتمعيـة

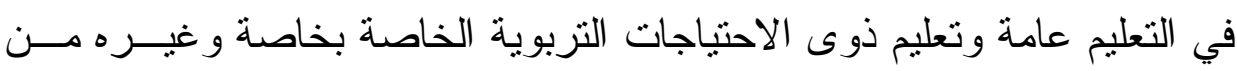

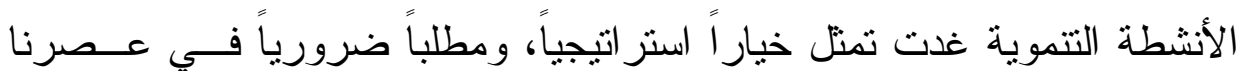
الر اهن، حيت أوضحت نتائج العديد من الدراسات أن المجتمعات التي ترتفع فيها

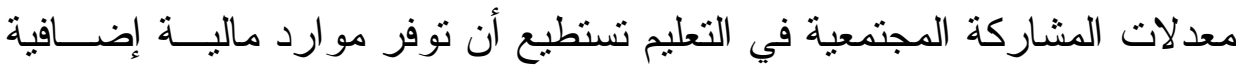

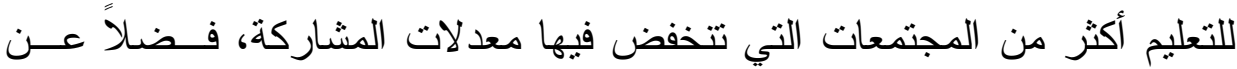

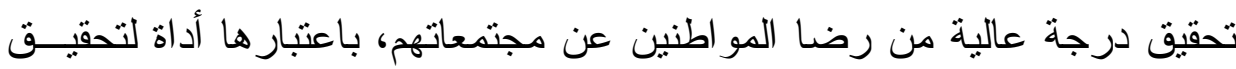

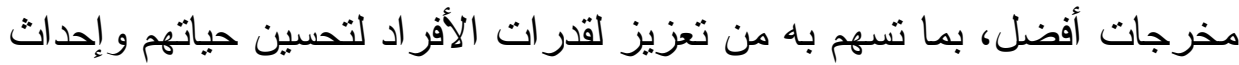
التغيير الاجتماعي ('). وفي سبيل تحقيق جودة حياة الأطفال ذوى الاحتياجات الثربوية الخاصــة

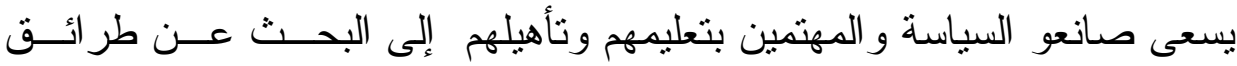
الاستفادة من المو ارد المتاحة بكفاءة لتوفير التعليم الجيد لهم. (ج) أهداف المشاركة المجتمعية

هناك شبه اتفاق علي أن هناك ثلاث غايات رئيسة لابد أن تفي بها التربية

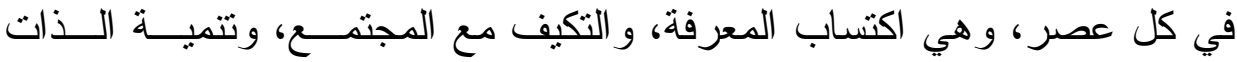
و القدر ات الثخصية، وقد أضاف عصر المعلومات بعداً نربوياً رابعاً، ألا وهــو

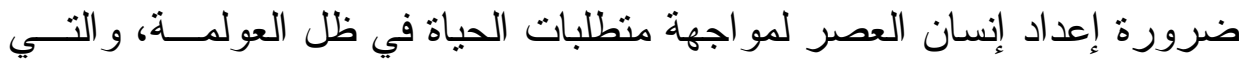

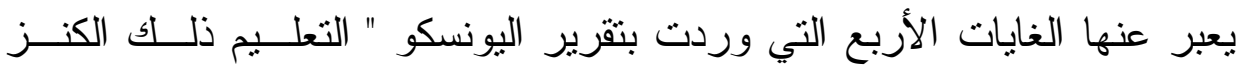

(') معهد التخطيط القومي، برنامج الأمم المتحدة الإمائي ، تقرير التتمية البشرية ، القاهرة، $. \Sigma 0, Y, . r$ 
المكنون " فلقد أوصت اليونسكو بضرورة أن يتعدى نظام التعليم في أهدافه تعليم

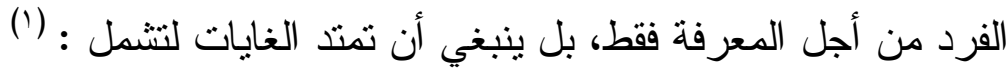
أ- التعليم من أجل العمل Learning to do، ويفرض علي التعليم المرونـــة، و العمل ضمن الفريق، و العمل من بعد، و العمل مع الحركة و الانتقال. ب- تعلم لتكون Learning to be، ويتطلب أن يكون لاى المـتـعلم إتجـــاه

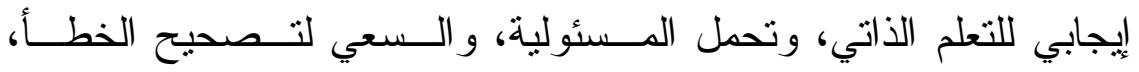
و الاستفادة من المصادر المتاحة.

جـ- تعلم لتعيش مع الأخرين Learning to live together، ويهدف إلـي ألـي

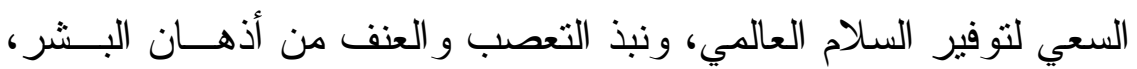

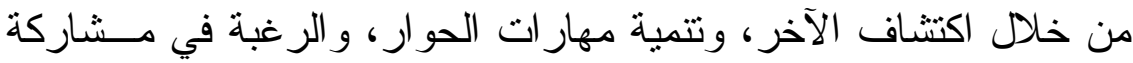

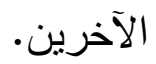

د- التعلم للمعرفــة Learning to Knowledge، أي كيفيــة البحــث عـن مصادر المعلومات.

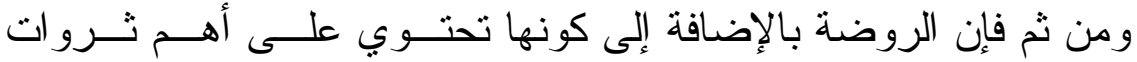

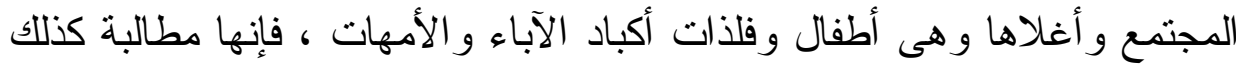
بنشر ثقافة المشاركة المجتمعية ، ومر اعاة اختلاف المؤسسات و المنظمات التـي تثناركها في اتخاذ القرار ات ، وتوثيق الرو ابط الثقافية و العلمية و الاجتماعية مسيح

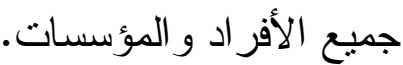

$$
\begin{aligned}
& \text { (1) نبيل علي : النقافة العربية وعصر المعلومات - رؤية لمستقبل الخطاب العربي الثقافي، مجلة }
\end{aligned}
$$

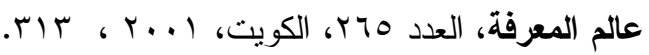


للمشاركة المجتمعية مجموعة من الأسس من أهمها أنها:

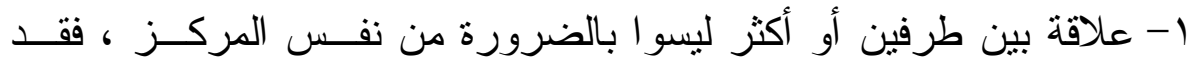

ينتمون إلى خلفيات ثقافية واجتماعية مختلفة وهي علاقـــة مرنــــة قابلــــة

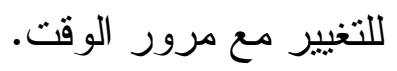

r- تتشأ من منطلق أن العمل النتشاركى قد يحقق مخرجــات كـل طــرف ، و التى قد لا تتحقق من خلال العمل المستقل وتقوم على التعاون و التطوع

$$
\text { و الوضوح و المحاسبة التبادلية.. }
$$

r- يكون للأطر اف المشاركة رؤى و أهداف و احدة ، ولكن ليس هذا شــرطاً

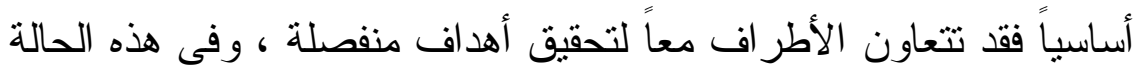

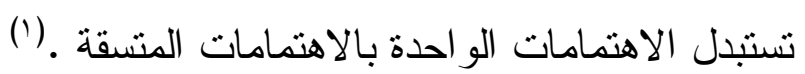

ع- يستطيع المتشاركون أن يتعاونو ا معاً إذا كانت لديهر: خصائص و أهـــاف

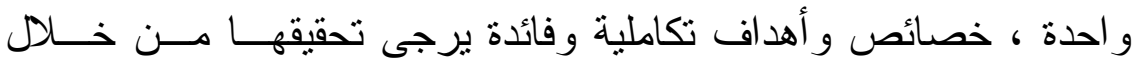

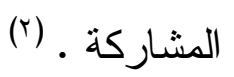

ه- لا ترتبط المشاركة المجتمعية بالر غبة فـى تحقيــق مكاسـب اجتماعيــة

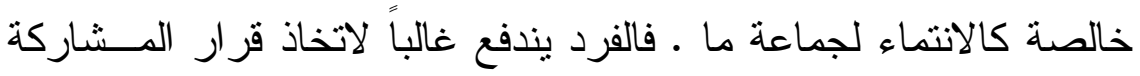

$$
\text { إذا كانت ستحقق له بعض المكاسب الثخصية . }
$$

(1) Wazir, Rekha \& Oudenhoven Nico V: Partnership - A Development Strategy for Children, Action Research in Family and Early Childhood, Early Childhood and Family Education Unit. UNESCC, 1998. P.11.

(2) Bracht, N., \& Tsouros, A. : Principles and strategies of effective community participation. Health promotion international, Vol.(5),No.(3), 1990,pp199208. 
؟- تستند إلي التفاهم و الثقة المنبادلة والخبرة وضمان تدفق المعلومات لجميع

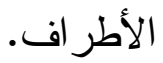

V- ضرورة وجود رؤيا و اضحة مشتركة وهدف محدد مشترك من قبل أفر اد

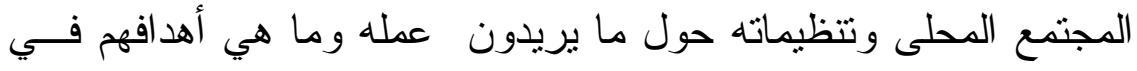

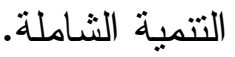

^- ضرورة اتخاذ بعض القرار ات ذات الأهمية في تخطيط بــر امج التتميـــة

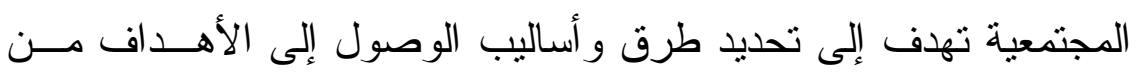

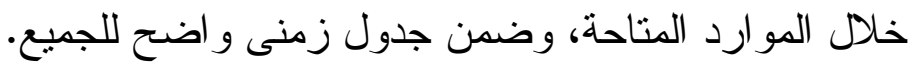
9- تحديد الموارد الخفية التى يمكن تضيع عند اتخاذ قرار ات فردية لاتقـوم على مبدأ الثمولية و النتاركية.

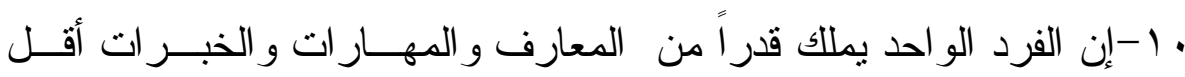

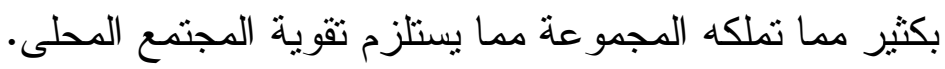

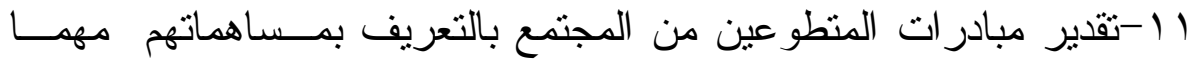
كانت بسيطة أو محدودة وتوفير الحو افز المادية و المعنوية المختلفة. r إإر الك أن المجتمع المحلى متغير و أنه من المستحيل أن يتم تبنى الحلول لمشكلة ما مرة و احدة و استخدامها لمر ات عديدة المئه المحور الثاني: الإطار التربوي لجودة الحياة لاى أسر الأطفال ذوي الاحتياجات

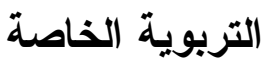
(أ) مفهوم جودة الحياة: يتضمن مفهوم جودة الحياة ما يلي: 1- الاستمتاع بالظروف المادية و الإحساس بحسن الحال. 


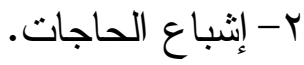

r- الرضا عن الحياة، و الحياة العاطفية الايجابية إلى جانب الصحة الجـسمية الايجابية، و إحساسه بمعنى السعادة وصو لا إلى عيش حياة متو افقــة بــين

$$
\text { جوهر الإنسان و القيم السائدة في المجتمع. }
$$

ع- أن مفهوم جودة الحياة من المفاهيم المحيرة نظر اً لاستخدامه فى كثير من المو اقف.

0- لا توجد نظرية محددة لجودة الحياة لينطلق منها التعريفات سالفة الذكر . צ- لا تقتصر المفاهيم السابقة على جانب الرضا فقط لكنها تمنذ إلى الجو انب

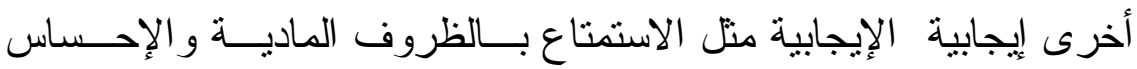

$$
\text { بحسن الحال }
$$

V- مفهوم جودة الحياة تحدده بعض المتغير ات الثقافية مما يجعل هنالك فروق

$$
\text { فى التعريفات بين الثقافات المختلفة. }
$$

1- يؤكد مفهوم جودة الحياة على المعنى المركب من عدة أبعاد تـشير إلـى بعض العو امل المتر ابطة التي تحتاج إلى فحص دقيق من أجل بناء نـسـق مفاهيمي وقابل للقياس و المتعلق بالرضـا المهني و المشـاركة فــي العمـلـل،

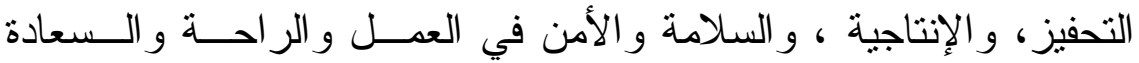
و الخصائص الثخصية للعمال ضمن محيط المنظمة ، وتطوير القدرات ،

$$
\text { التو افق بين الحياة في و العمل وخارجها. }
$$

9-وتشير بعض التعريفات إلى أن مفهوم جودة الحياة يمكن تقييمــهـ عنــدما يكون هناللك شعور ايجابي اتجاه أعمالهم وتقاءل مستقبلي نحسـو مسـسار هم مما يحفز الاستمر ار في العمل و الإحساس الايجابي اتجاهه و التو افق بــين 
حياة العمل النشيطة و الحياة الثخصية مما يؤدي إلى إحداث التوازن بـين هذين المتغيرين.

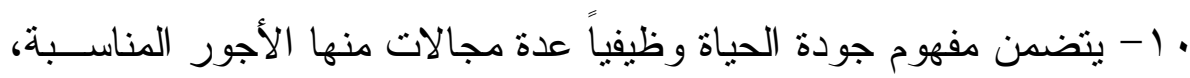

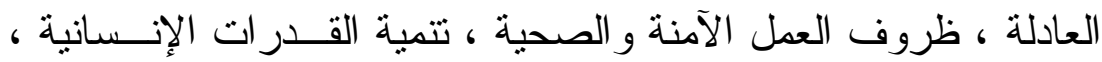

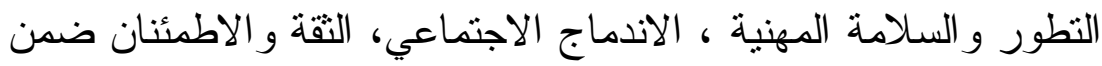

$$
\text { الوسط الاجتماعي العام. }
$$

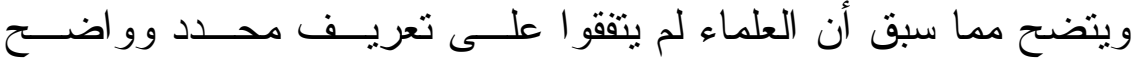

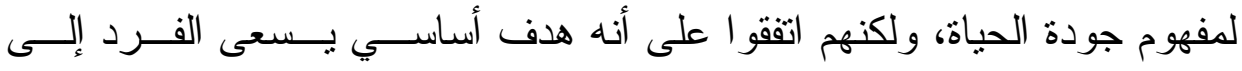

تعتمد جودة الحياة على عدة أبعاد ومعايير من أهمها الـصحة الجسمية

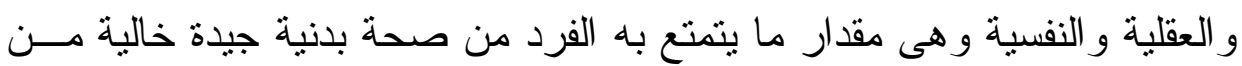

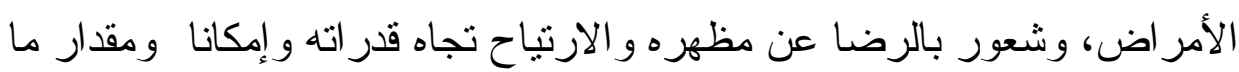

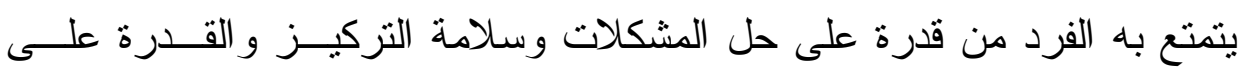

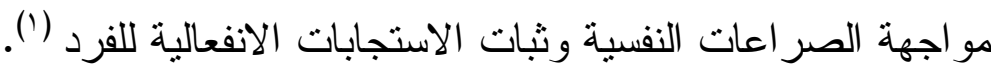
ومن معايير جودة الحياة أيضا الخصائص الثخصية الـسرية كالـــلابة

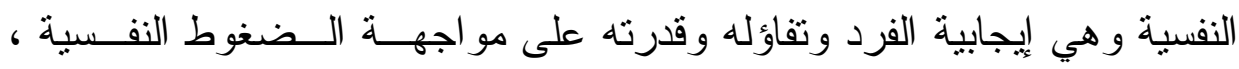

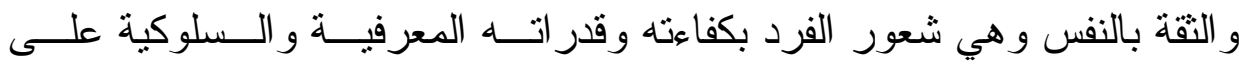

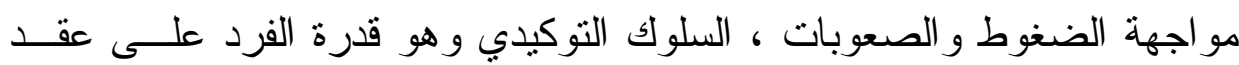

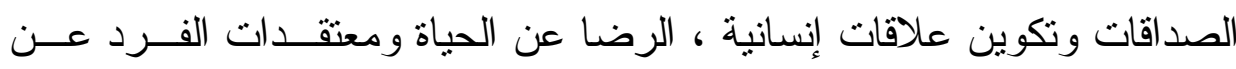
(1) زنيب محمود شقير : مقياس تثخيص معايير جودة الحياة (للعاديين وغير العاديين)، كلية

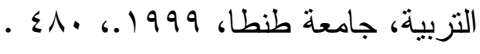


موقعه في الحياة و أهدافه وتوقعاته ومعاييره و اهتماماته في ضوء السياق التقافي

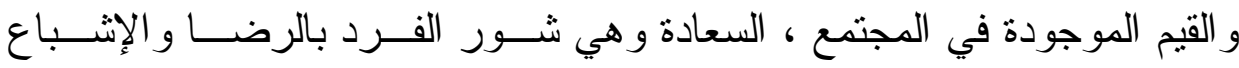

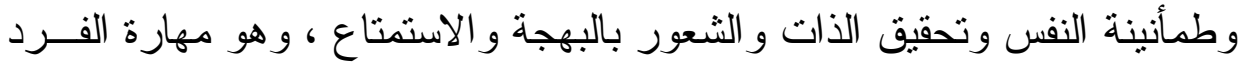

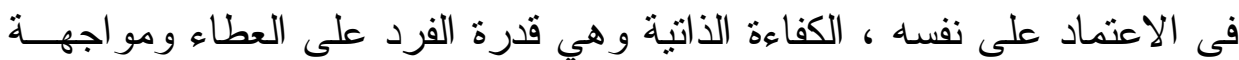

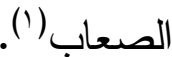

وتوجد أيضاً المعايير الخارجية لجودة الحياة كالانتمــاء وهـــــــالارتبــاط

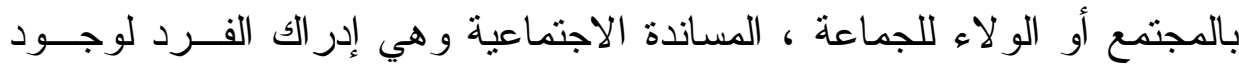

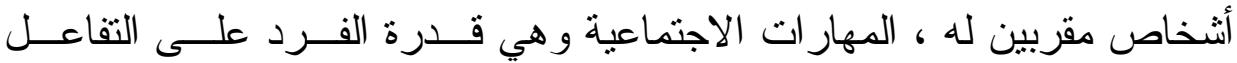
الاجتماعي، المكانة الاجتماعية وهي شعور الفرد بقيمته ومكانته داخل الجماعة، العمل و هي الوظيفة التي ييرز فيها الفرد قدر اته و إمكانياته فــي الأداء ، القـئه الدينية و الخلقية و الاجتماعية وهي مجموعة المبادئ و القو اعد و المنل العليا التـي ولي

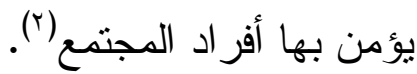
كما يمكن أيضاً تقسيم أبعاد جودة الحياة إلى جودة الحياة الصحية، وجودة التعليم و الدر اسة، أو جودة المناهج و المقرر ات الدر اسية، وجودة الحياة الأسرية،

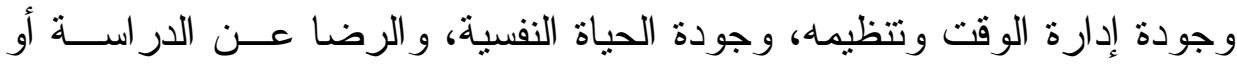
التخصص، وجودة المساندة من الزملاء و المدرسين، وجـــودة الكفــــاءة الذاتيـــة

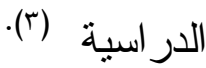

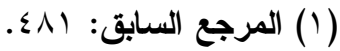

(Y) صلاح الدين محمد عر اقي و مصطفى على مظلوم: فاعلية برنامج ارشادي لتحسين جودة الحياة

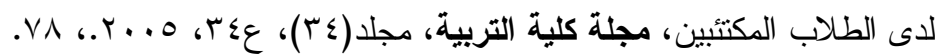

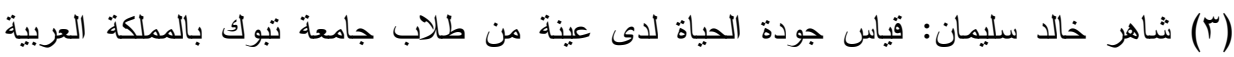

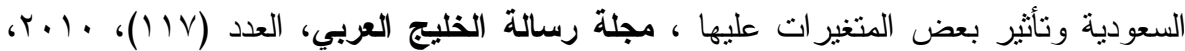




\section{مما سبق من أبعاد يتضح ما يلي :}

ا- تعد جودة الحياة فى العصر الحالى هدفا تسعى نحو تحقيقه كافــة أنظــــة

$$
\text { المجتمع الاقتصادية و السياسية و الاجتماعية و التعليمية. }
$$

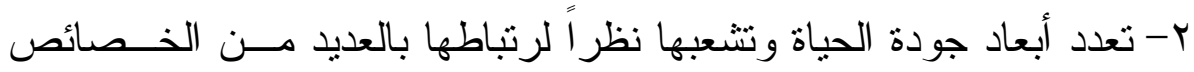

$$
\text { منها الجسمية و الصحية، و النفسية، الاجتماعية. }
$$

r- إن تلك الأبعاد منها ما يرتبط بالخصائص الداخلية للفرد، ومنها ما يرتبط بالبيئة الخارجية ومدى انعكاسها على الفرد وتحقيق الرضـا الثخصي لــــ

$$
\text { وتحقيق طموحه. }
$$

(ج) معوقات جودة الحياة: توجد العديد من الأسباب التى تعوق الإنـسان عـن

$$
\begin{aligned}
& \text { الثعور بجودة الحياة ومن هذه المعوقات: } \\
& \text { 1- } \\
& \text { r- فقدان الشعور بمعنى الحياة. } \\
& \text { r- قلة الوازع الدينى. }
\end{aligned}
$$

ع - ضعف توفير سبل الرعاية الصحية الكاملة للأفر اد.

0- افتقاد الكثير من الأفر اد للذكاء الوجدانى فى التصرف فى مو اقف الحياة

المختلفة.

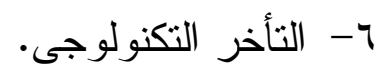

- V - V - V - V 
المحور الثالث: آليات المشاركة المجتمعية لتحسين جودة الحياة: لتفعيل

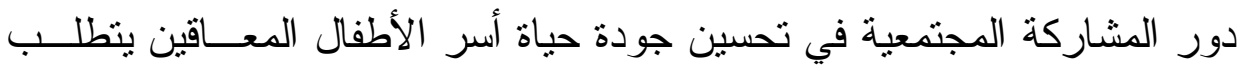
مجمو عة من الآليات يمكن إجمالها فيما يلي:

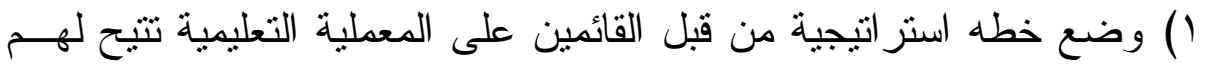

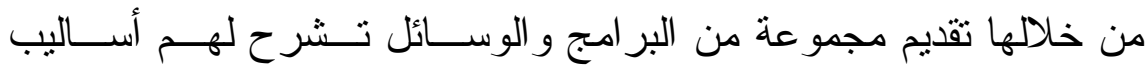

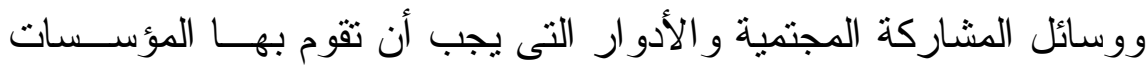
المختلفة ومنها الأسرة في تحسين جودة الحياة لهؤلاء الأطفال. r) عقد ورش وندوات ومؤتمرات لتوعية أفراد أسر الأطفال ذوي الاحتياجات

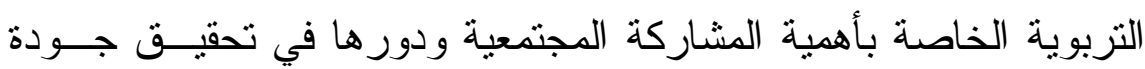
حياة هؤ لاء الأطفال. ץ) ضرورة تتظيم مر اكز لتدريب وتو عية الأسر المختلفة بأهميــة المـشـاركة المجتمعية ودور ها في تحقيق جودة حياة هؤ لاء الأطفال.

ع) وضع لو ائح وقو اعد لضبط تتظم المشاركة المجتمعية بين الأسرة و غيرها

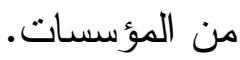

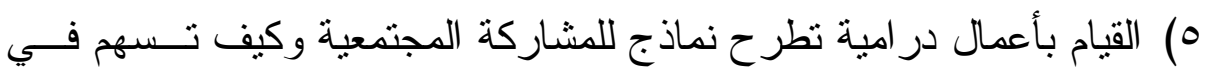

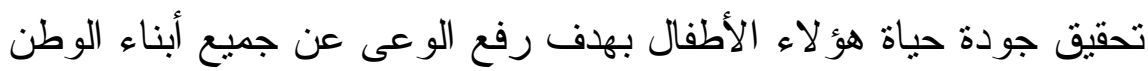

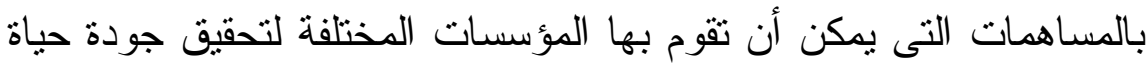
الطفل من ذوي الاحتياجات النربوية الخاصة.

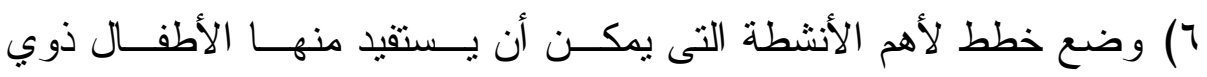

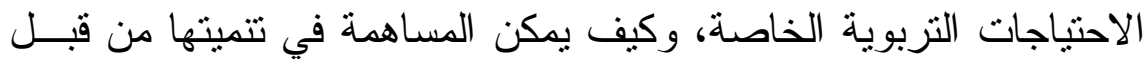

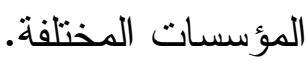


V) توفير الرعاية المتكاملة لذوي الاحتياجات التزبوية الخاصــة مــن قبـلـ

$$
\text { منظمات المجتمع المدني }
$$

^) استقبال الثركات و المصانع للأطفال وتقديم المنتجات و الهــــايا للأطفــال ذوي الاحتياجات التزبوية الخاصة

$$
\text { 9) نتظيم لقاءات حوارية لدعم المشاركة المجتمعية }
$$

• (1) تشجيع تبرع رجال الأعمال بنوفير التجهيز ات لتحسين مستوى مؤسـسة

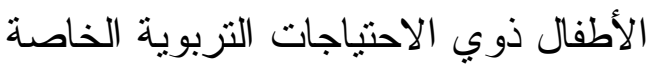
(1) مشاركة أولياء الأمور في صناعة القرار ات المتعلقة بأطفالهم r (1)نشر ثقافة المشاركة بين الأسرة ومؤسـسـة الأطفــال ذوي الاحتباجـات التزبوية الخاصة عبر وسائل الإعلام المختلفة

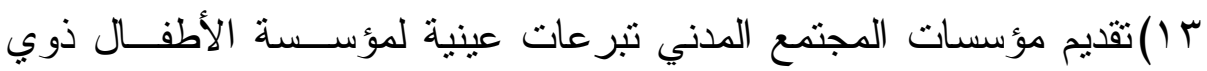
الاحتياجات النزبوية الخاصة لتنفيذ أنشطتها ـ ( ) أثبر ع بالملابس و الأدوات الفائضة لتوزيعها على الأطفال الفقر اء 10)عقد مؤسسة الأطفــال ذوي الاحتياجـات التزبويــة الخاصــة نــدوات

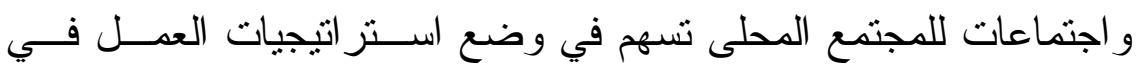

$$
\text { المؤسسة }
$$

$$
7 \text { (1) تفعيل مجالس الأمناء بصورة دورية ومنظمة وهادفة }
$$

V) وضع ضو ابط للحفاظ على المشاركة بين الأسرة ومؤسسة الأطفـال ذوي

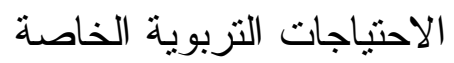




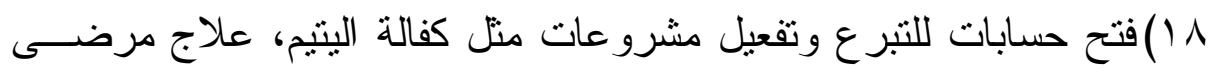

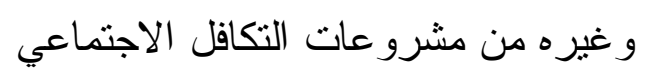

9 (1) أستضيف الأطفال الفقر اء في الإجاز ات لرفع معنوياتهم وتخفيف المعانــاة

$$
\text { عنه }
$$

• ب) نشر الوعي بأهمية المشاركة من خلال الاجتماعات و الندوات و الكتيــات

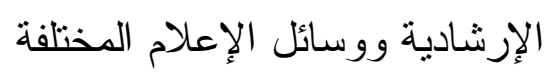

(Y) دعوة مؤسسة الأطفال ذوي الاحتياجات التزبوية الخاصة المتخصـصين

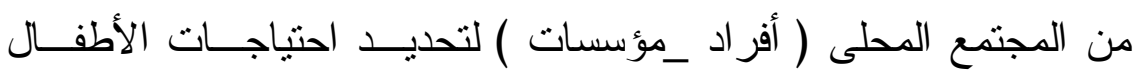
التربوية ووضع قو اعد وخطط لتتفيذها

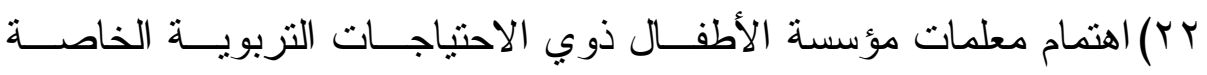
بتحقيق العدالة و المساو اة بين أولياء الأمور

بr) تمويل الجمعيات الأهلية لمؤسسة الأطفــال ذوي الاحتياجـات التربويــة الخاصة

\section{در اسات مقترحة}

و لإتمام الفائدة تقترح الباحثة إجر اء الدراسات الآتية:

- در اسة تقويمية لدور المشاركة المجتمعية في رعاية الأطفال ذوي الاحتياجات

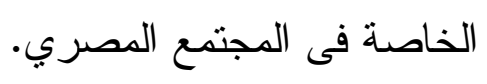

- دور المؤسسات الأهلية فى تحقيق جودة حبــاة الأطفــال ذوي الاحتياجـات

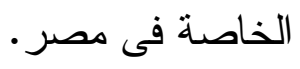


- خروج المر أة للعمل و انعكاسه على رعاية الأطفال ذوي الاحتياجات التربوية الخاصة من أفر اد أسرتها.

- تحديد الاحتباجات التربوية الفعلية لأسر ذوي الاحتياجات الخاصة فــي ظـلـل المتغير ات المجتمعية المعاصرة.

- در اسة نقدية للبحوث المنشورة في الدول العربية حول المشاركة المجتمعيـة وجودة الحياة في ضوء أهدافها.

- تقويم سياسة رعاية الأطفال ذوي الاحتياجــات الخاصــة بــين الــسياسات الوضعية و التصور الإسلامي. توعي. الاطعال دوي 


$$
\text { أولا : المر اجع الدراسة العربية }
$$

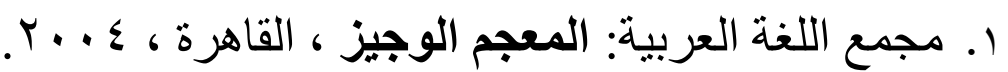

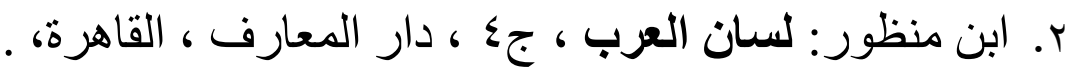

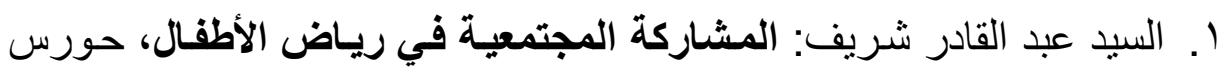

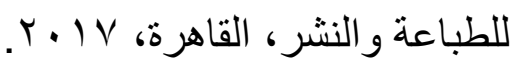

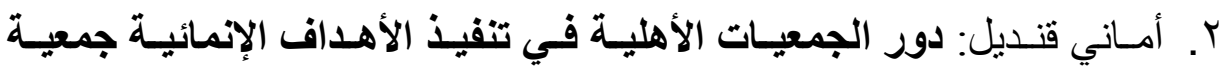

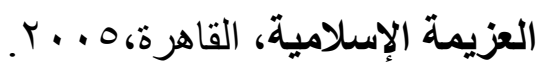

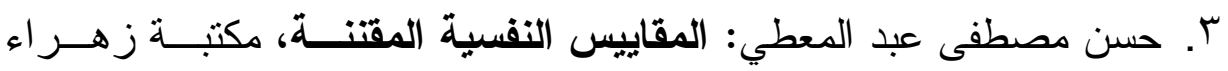

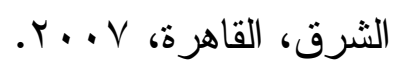

ع. عبد الباسط عبد المعطى: علم اجتماع التنمية، قضايا معاصــرة ، جامعــة

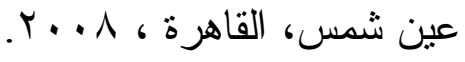

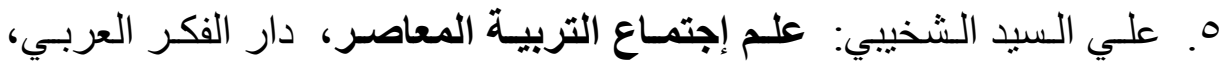

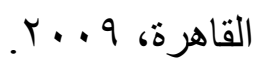

7. عثمان لبيب فر اج: الإعاقات الذهنية في مرحلة الطقولة، المجلس العربـي

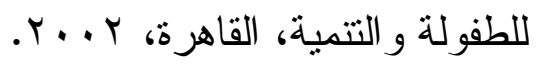

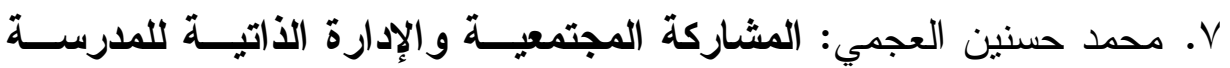

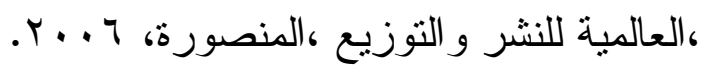

المجلد الرابع


^. معهـ التخطـيط القومي، برنـامج الأمــم المتحـدة الإنمـائي ، تقريـر التتميـة

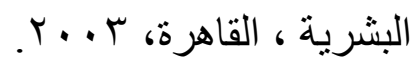

$$
\text { رسائل الماجستير والدكثوراه }
$$

ا . حسن عبد المجيد أبو طه: تصور مقترح لتحقيق جودة حياة الطفل المصري من ذوي الاحتياجات التزبوية الخاصة ومدى تو افر ها فى أســرته، رســـالة ماجستير غير منشورة، كلية التزبية، جامعة طنطا، ا ا ب r.

$$
\text { المؤتمرات والدوريات العربية }
$$

ا. إميل فهمي شنودة : فعالية المشاركة الثعبية في التنمية المحلية التربوية في جمهورية مصر العربية: دراسة مستقبلية ، دراسة مقدمة إلى المؤتمر العلمي السنوي التاسع (التربية وتنمية ثقافة المشاركة وسلوكياتها في الوطن

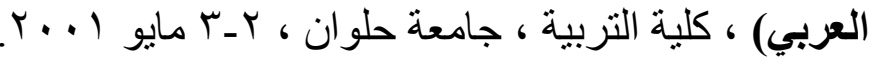

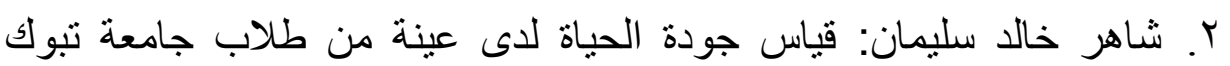
بالمملكة العربية السعودية وتأثثر بعض المتغيرات عليها ، مجلة رسالة

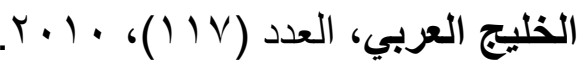

r. محمد السعيد أبو حلاوة: "جودة الحياة المفهوم والأبعاد "، المؤتمر العلمي السابع "جودة الحياة كاستثمار للعلوم التربوية والنفسية، كلية التربية،

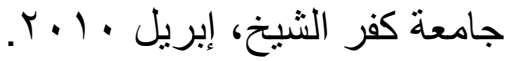

ع. نبيل علي : الثقافة العربية وعصر المعلومات ـ رؤية لمستقبل الخطاب

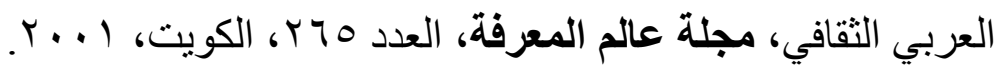

ثانيا : المر اجع الأجنبية 
1. Bracht, N., \& Tsouros, A. : Principles and strategies of effective community participation. Health promotion international, Vol.(5),No.(3), 1990,pp199-208.

2. Pryor, J. : Can community participation mobilise social capital for improvement of rural schooling? A case study from Ghana. Compare: A Journal of Comparative and International Education, Vol.(2), No.(35), 2005,pp 193203.

3. Talò, C., Others :Sense of community and community participation: A meta-analytic review. Social indicators research, $\operatorname{Vol}(1), \operatorname{No}(117), 2014, p p$ 1-28.

() Pryor, J. : Can communi

4. Warner, K., Hull, K., \& Laughlin, M. :The Role of Community in Special Education: A Relational Approach. In Interdisciplinary Connections to Special Education: Important Aspects to Consider, 2015, (pp. 151-166). Emerald Group Publishing Limited.

5. Wazir, Rekha \& Oudenhoven Nico V: Partnership - A Development Strategy for Children , Action Research in Family and Early Childhood, Early Childhood and Family Education Unit. UNESCC, 1998. P.11. 